\title{
Evaluation of secondary metabolites of herbal plant extracts as an antiviral effect on infectious bursal disease virus isolates in embryonated chicken eggs
}

\author{
Rawaa Saladdin Jumaa1(D), Dhuha Ismael Abdulmajeed ${ }^{1}$ (D) and Abdulkarim Jafar Karim² (D)
}
1. Department of Microbiology, College of Veterinary Medicine, University of Baghdad, Baghdad, Iraq; 2. Unit of Zoonotic Diseases, College of Veterinary Medicine, University of Baghdad, Baghdad, Iraq.
Corresponding author: Abdulkarim Jafar Karim, e-mail: abdalkarem@covm.uobaghdad.edu.iq
Co-authors: RS]: rawaa.saladdin@covm.uobaghdad.edu.iq, DIA: dhuha.e@covm.uobaghdad.edu.iq Received: 14-07-2021, Accepted: 12-10-2021, Published online: 25-11-2021

doi: www.doi.org/10.14202/vetworld.2021.2971-2978 How to cite this article: Jumaa RS, Abdulmajeed DI, Karim AJ (2021) Evaluation of secondary metabolites of herbal plant extracts as an antiviral effect on infectious bursal disease virus isolates in embryonated chicken eggs, Veterinary World, 14(11): 2971-2978.

\begin{abstract}
Background and Aim: Infectious bursal disease attacks the poultry industry, mainly young chickens, causing immunosuppression, and death with high economic losses. This study aimed to evaluate the effects of the monoextract, diextracts, and triextracts of Quercus infectoria (QI), Citrus aurantifolia (CiA), and Coffea arabica (CoA) on infectious bursal disease virus (IBDV) in embryonated chicken eggs (ECEs).

Materials and Methods: The experimental design consisted of three sets of ECEs at 11 days of age, and each set included seven groups (G1-G7). The extracts of QI, CiA, and CoA were inoculated to ECEs by the chorioallantoic membrane method before, in concomitant (mixed) with, and after IBDV infection to the first, second, and third sets, respectively. The monoextract, diextracts, and triextracts of QI, CiA, and CoA were given at 1\%, 2\%, 5\%, and 10\% concentrations to G1-G3, G4-G6, and G7, respectively. Real-time polymerase chain reaction identified and confirmed the virus in accordance with the pathological changes.

Results: The monoextract $(5-10 \%$ concentrations) inhibited IBDV and had no effect on viral infection preinoculation, whereas the monoextract (10\% concentration) inhibited IBDV during mixed inoculation and post-inoculation. Diextracts (2-10\% concentrations) inhibited IBDV and had no effect on viral infection preinoculation, whereas diextracts $(5-10 \%$ concentrations) inhibited IBDV during mixed inoculation and post-inoculation. Triextracts $(1 \%, 2 \%, 5 \%$, and $10 \%$ concentrations) inhibited IBDV by ameliorating the pathological changes of the virus and preventing the death of ECEs.
\end{abstract}

Conclusion: The inoculation of herbal extracts, particularly triextracts, alleviates the pathological changes in ECEs infected with IBDV. This study recommends the oral route in evaluating plant extracts against IBDV in poultry.

Keywords: chick embryo, herbal plant, infectious bursal disease virus, Iraq.

\section{Introduction}

Infectious bursal disease (IBD) is caused by a virus that belongs to the Birnaviridae family, called the IBD virus (IBDV). The disease attacks the poultry industry, mainly the bursa of Fabricius of young chickens, causing immunosuppression, vaccine failure, secondary infections, and death with high economic losses [1-3]. IBDV is incriminated in the destruction of the bursa of Fabricius, resulting in the lack of B lymphocytes, which is responsible for humoral immunity [4]. Therefore, immunosuppression and weak immunity make chickens prone to various diseases and vaccination failure [5]. Immunomodulation is a major concern in poultry farms, and innovative products at reasonable rates that can help improve or avoid such diseases are critical for the poultry industry as well as humans $[6,7]$.

Copyright: Jumaa, et al. Open Access. This article is distributed under the terms of the Creative Commons Attribution 4.0 International License (http://creativecommons.org/licenses/by/4.0/), which permits unrestricted use, distribution, and reproduction in any medium, provided you give appropriate credit to the original author(s) and the source, provide a link to the Creative Commons license, and indicate if changes were made. The Creative Commons Public Domain Dedication waiver (http://creativecommons.org/ publicdomain/zero/1.0/) applies to the data made available in this article, unless otherwise stated.
Herbal medicine has a promising value at present. It is frequently used in treating many diseases, including incurable ones [8-12]. Such herbal medicines include those derived from Quercus infectoria (QI), Citrus aurantifolia (CiA), and Coffea arabica (CoA). Oak galls (QI), such as many other herbs, have many bioactivities, such as antiviral, antioxidant, antifungal, antibacterial, larvicidal, anti-inflammatory, antiamoebic, antidiabetic, antivenin, and wound healing [13-15]. QI extract has long been used to treat a variety of ailments and for health promotion [13]. Dried lime (CiA) is high in Vitamin $\mathrm{C}$ with antioxidant, antimicrobial, diuretic, detoxifying, and anthelminthic properties [16-20] and is used to strengthen the stomach, intestinal, and heart muscles and prevent osteoporosis. These effects are aided by the presence of calcium and riboflavin in the diet. CiA is added as traditional seasoning to meals and taken as herbal tea to treat certain diseases in the Middle East [21]. Coffee (CoA) is among the most widely consumed drinks on the planet, accounting for roughly one-third of the global consumption [22]. It is used as an adsorbent for toxic metals, bioactive composites, and pharmaceutical and cosmetic industries [23-27]. The antioxidant 
and antimicrobial properties of coffee are attributed to its high polyphenol, flavonoid, dietary fiber, caffeine, and chlorogenic acid content $[25,28,29]$.

Evaluating the efficacy of a purified herbal extract is usually studied using an antioxidant assay, an oxygen radical absorbance ability assay, or a free radical method [30-35]. Moreover, these extracts have antiviral properties that can be enhanced synergistically by combining them with other supplements. Poultry farms have commonly used natural medicinal products as feed supplements with immune-stimulant and stress-relieving properties [36-42].

This study aimed to evaluate the effects of QI, $\mathrm{CiA}$, and $\mathrm{CoA}$ extracts in ameliorating the pathological changes associated with IBDV infection.

\section{Materials and Methods}

\section{Ethical approval}

All procedures followed the guidelines of the Animal Care and Use Committee and approved under no. ACUC/2517 on 25 May 2020.

\section{Study period and location}

The study was conducted from September 15, 2020 to January 21, 2021. The study was carried at the Laboratory of Virology, Department of Microbiology, College of Veterinary Medicine, University of Baghdad.

\section{Sample collection}

Twenty samples (bursa of Fabricius) were collected from chickens suspected of having Gumboro disease (IBD) in various areas of Iraq's Baghdad government. Bursa of Fabricius samples were prepared according to Mutinda et al. [43] and stored in $2 \mathrm{~mL}$ Eppendorf tubes at $-20^{\circ} \mathrm{C}$ until use.

\section{Viral detection using real-time polymerase chain reaction ( $R T-P C R$ )}

RNA bursal cells were isolated and purified using a kit from Qiagen. Viral amplification was carried out by RT-PCR using kits from Genekam Biotechnology AG. Primers (short nucleic acid sequence used in PCR) were used to perform a molecular diagnosis of RNA derived from samples suspected of being infected with IBDV.

Viral propagation in embryonated chicken eggs (ECEs) through chorioallantoic membrane (CAM)

The prepared samples were inoculated on CAM according to Mutinda et al. [43].

\section{Determination of $50 \%$ embryonated lethal dose (ELD50) of IBDV}

Virus titer was determined by the pathological changes of IBDV in ECEs and expressed as ELD ${ }_{50}$ per milliliter using the formula of Reed and Muench [44].

\section{Preparation of plant extracts}

Each plant was extracted using 70\% $(1: 5, \mathrm{w} / \mathrm{v})$ methanol according to El-Rabey et al. [45].

\section{Detection of phytochemical agents}

The detection of the phytochemical agents of each extract was carried out according to Harborne [46].
Preparation of stock solution of QI, CiA, and CoA extracts

Ten grams each of QI, CiA, and CoA in $10 \mathrm{~mL}$ sterilized distilled water were used to make a stock solution for each extract. The toxicity of each extract was measured using ECEs at various concentrations $(1 \%, 2 \%, 5 \%$, and $10 \%)$.

\section{Study design}

The study design consisted of three sets of treatments. These sets were infected with IBDV and treated with plant extracts at $1 \mathrm{~h}$ before, 0 time, and $1 \mathrm{~h}$ after viral inoculation (Table-1). For each set, seven groups of chick embryos, five each, were treated as follows: Monoextract QI, monoextract CiA, monoextract CoA, diextracts QI and CiA, diextracts QI and CoA, diextracts $\mathrm{CiA}$ and $\mathrm{CoA}$, and triextracts QI, CiA, and CoA. The effect was observed for 5 days after inoculation.

\section{Toxicity test}

According to Eladl et al. [5], the acute toxicity for each extract (monoextract, diextracts, and triextracts) was determined as $\mathrm{LD}_{50}$ in ECEs. In a nutshell, 12 (11-day-old) ECEs were inoculated with three doses of 1,10 , and $100 \mathrm{~g} / \mathrm{mL}$ of each plant extract (monoextract, diextracts, and triextracts)/distilled water, with one group of ECEs serving as the untreated control group. Toxicity symptoms include the death of ECEs after $24 \mathrm{~h}$. Every plant extract (monoextract, diextracts, and triextracts) showed no signs of toxicity or mortality in ECEs according to the toxicity test.

\section{RT-PCR for harvested CAM in treated ECEs}

Harvested virus (CAM) from treated and infected ECEs was tested using RT-PCR.

\section{Results}

Methanolic extracts of QI, CiA, and CoA

According to Banso and Adeyemo [47], the methanolic extracts of QI, CiA, and CoA produced dark-brown crystals, dark-brown sticky oil, and golden yellow crystals at $64 \%, 42 \%$, and $19 \%$, respectively.

\section{Phytochemical agents}

The phytochemical analysis of each methanolic extract revealed the existence of all secondary metabolic agents, except for resin, steroid, and saponin, as shown in Table-2.

\section{Toxicity of extracts}

According to the toxicity test, no signs of toxicity or mortality in ECE occurred within $24 \mathrm{~h}$ in all plant extracts.

\section{IBDV diagnosis}

Of 20 samples, only eight bursa of Fabricius samples were confirmed positive for IBDV using RT-PCR (Figure-1).

\section{Pathological changes}

Positive samples were used to inoculate ECEs using RT-PCR. Three days after infection, pathological changes were observed. The first passage revealed no changes in the embryo and monitored ECEs, but 
Table-1: Design of the study.

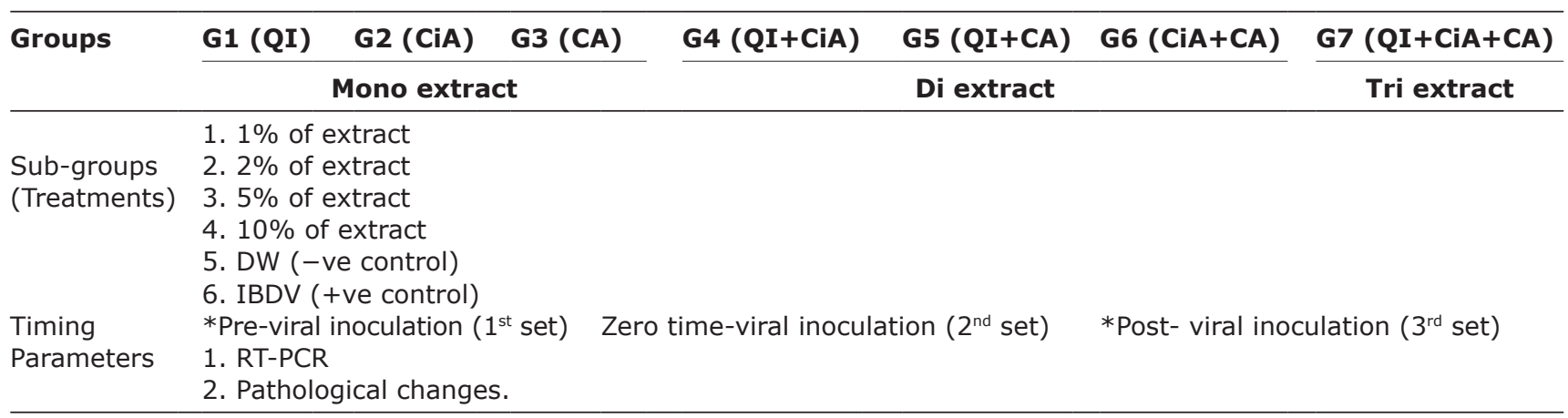

QI=Quercus infectoria, CiA=Citrus aurantifolia, CoA=Coffea arabica, DW=Distilled water, IBDV=Infectious bursal disease virus $*(1 \mathrm{~h})$. RT-PCR $=$ Real-time polymerase chain reaction

Table-2: Phytochemical analysis of Quercus infectoria (QI), Citrus aurantifolia (CiA) and Coffea arabica (COA).

\begin{tabular}{lccc}
\hline Phytochemicals (Active components) & QI & CiA & CoA \\
\hline Tannin & + & + & + \\
Phenol & + & + & + \\
Saponin & + & + & - \\
Flavonoid & + & + & + \\
Steroid & + & - & - \\
Terpenoid & + & + & + \\
Glycoside & + & + & + \\
Resin & - & + & - \\
Alkaloid & + & + & + \\
\hline
\end{tabular}

$+=$ Present, $-=$ Not present.

the second passage revealed death and dwarfing of the infected embryo and hemorrhage on the infected embryo's body (Figure-2a). In contrast, the control showed no changes (Figure-2b).

\section{Titration of isolated IBDV in ECEs $\left(E\right.$ LD $\left._{50}\right)$}

In ECEs, the second passage titer for the first isolated IBDV was $10^{3} / 100 \mu \mathrm{L}$, whereas the second passage titer for the second isolated IBDV was $10^{2.5} / 100 \mu \mathrm{L}$. The effect of herbal plant extracts on ECEs infected with IBDV is explained in Table-3.

\section{RT-PCR for harvested CAM in treated ECEs with} herbal plants

RT-PCR effectively detected IBDV inoculated on CAM with triextracts at $50 \%$ concentration, as shown in Figure-3.

\section{Discussion}

The effects of three plants, alone (monoextract) or mixed (diextracts and triextracts), on ECEs infected with IBDV were investigated in this study. RT-PCR was used to detect viral protein 2 (VP2), the spike of the very virulent strain of IBDV (vvIBDV). This is in line with the findings of Jumaa et al. [48], who detected the Iraqi strain of IBDV using RT-PCR and isolated it using fibroblasts of ECEs. Therefore, these results agreed with Cheggag et al. [49], who reported that this technique could detect highly virulent IBDV strains from classic and variant IBDV strains. These

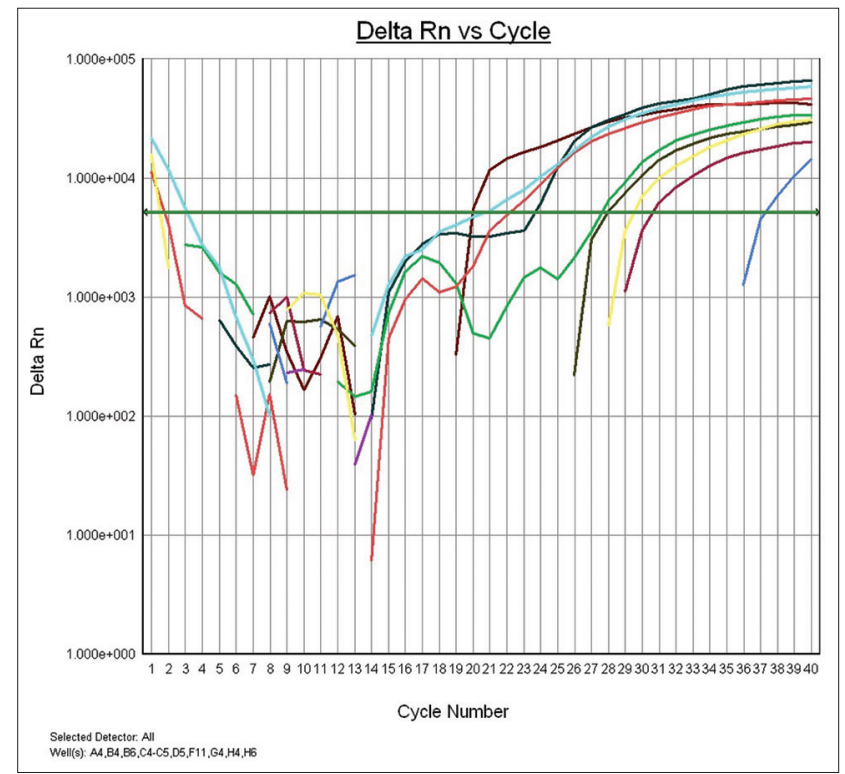

Figure-1: A plot of amplification of the viral protein 2 gene by real-time polymerase chain reaction for detection of infectious bursal disease virus revealed positive bursa of Fabricius samples.

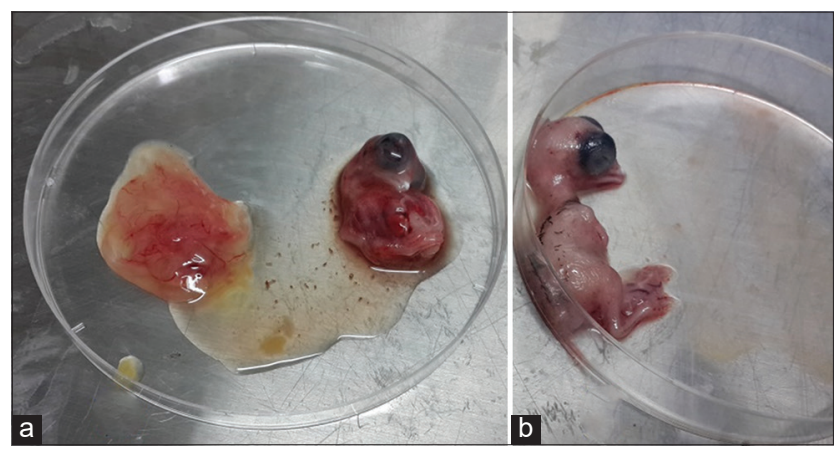

Figure-2: Infectious bursal disease virus-infected embryonated chicken eggs display pathological changes. (a) Infected (b) control.

results also agree with Jumaa et al. [50], who confirmed the VP2 of Iraqi vvIBDV strain using sequence analysis.

In this study, plant extracts were inoculated on ECEs against IBDV challenge during preincubation, 0 time (mixed), and post-infection (Table-3). The monoextract $(5-10 \%$ concentrations) inhibited IBDV and 
Table-3: Effect of secondary metabolic agents in ameliorating pathological changes of IBDV of pre-, mixed-, and post-treated extract.

\begin{tabular}{|c|c|c|c|c|c|c|c|c|}
\hline Time & Treatments & G1 (QI) & G2 (CiA) & G3 (COA) & $\begin{array}{c}\text { G4 (QI } \\
\text { and CiA) }\end{array}$ & $\begin{array}{c}\text { G5 (QI } \\
\text { and CoA) }\end{array}$ & $\begin{array}{c}\text { G6 (CiA } \\
\text { and CoA) }\end{array}$ & $\begin{array}{c}\text { G7 (QI \& CiA } \\
\text { and CoA) }\end{array}$ \\
\hline \multirow[t]{6}{*}{ Pre-treated } & DW & $-v e$ & $-v e$ & $-v e$ & $-v e$ & $-v e$ & $-v e$ & $-v e$ \\
\hline & IBDV & DP & DP & DP & DP & DP & DP & $\mathrm{DP}$ \\
\hline & $1 \%$ extract & D48* & D48* & D48* & D72* & D72* & D72* & $-v e$ \\
\hline & $2 \%$ extract & D72* & D72* & D72* & -ve & -ve & -ve & $-v e$ \\
\hline & $5 \%$ extract & -ve & -ve & -ve & $-v e$ & $-v e$ & -ve & $-v e$ \\
\hline & $10 \%$ extract & $-v e$ & $-v e$ & $-v e$ & $-v e$ & $-v e$ & -ve & $-v e$ \\
\hline \multirow[t]{6}{*}{ Mixed-Treated } & DW & $-v e$ & $-v e$ & $-v e$ & $-v e$ & $-v e$ & - ve & $-v e$ \\
\hline & IBDV & DP & DP & DP & DP & DP & DP & $\mathrm{DP}$ \\
\hline & $1 \%$ extract & D48* & D48* & D48* & D72* & D72* & D72* & - ve \\
\hline & $2 \%$ extract & D72* & D72* & D72* & D98* & D98* & D98* & - ve \\
\hline & $5 \%$ extract & D98* & D98* & D98* & -ve & -ve & -ve & $-v e$ \\
\hline & $10 \%$ extract & $-v e$ & -ve & -ve & $-v e$ & -ve & -ve & - ve \\
\hline \multirow[t]{6}{*}{ Post-Treated } & DW & $-v e$ & $-v e$ & $-v e$ & $-v e$ & $-v e$ & -ve & $-v e$ \\
\hline & IBDV & DP & DP & DP & DP & DP & DP & $\mathrm{DP}$ \\
\hline & $1 \%$ extract & D48* & D48* & D48* & D72* & D72* & D72* & $-v e$ \\
\hline & $2 \%$ extract & D72* & D72* & D72* & D98* & D98* & D98* & $-v e$ \\
\hline & $5 \%$ extract & D98* & D98* & D98* & -ve & $-v e$ & -ve & $-v e$ \\
\hline & $10 \%$ extract & $-v e$ & -ve & -ve & $-v e$ & $-v e$ & $-v e$ & $-v e$ \\
\hline
\end{tabular}

$\mathrm{DW}=$ Distilled water, IBDV $=$ Infectious bursal disease virus, - ve $=$ No death, $D=$ Death, $P=$ Pathological changes, $D P=D e a t h$ and pathological changes, $(*)$ : death time (hours). QI=Quercus infectoria, CiA=Citrus aurantifolia, CoA: Coffea arabica

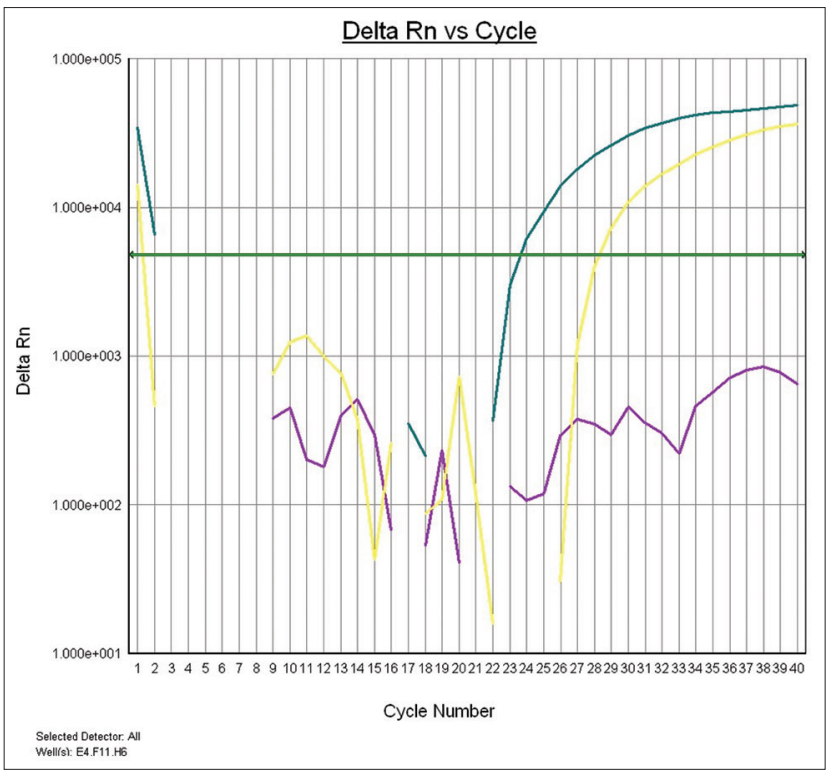

Figure-3: Plot of amplification RT-real time PCR for viral protein 2 gene in harvested chorioallantoic membrane. The green line refers to the $50 \%$ triextract group, yellow line refers to positive control, and the violet line as negative control.

had no effect on viral infection preinoculation, whereas the monoextract ( $10 \%$ concentration) inhibited IBDV during mixed and post-inoculation. Diextracts $(2 \%$, $5 \%$, and $10 \%$ concentrations) inhibited IBDV and had no effect preinoculation, whereas diextracts $(5-10 \%$ concentrations) inhibited IBDV during mixed inoculation and post-inoculation. Triextracts $(1 \%, 2 \%, 5 \%$, and $10 \%$ concentrations) inhibited IBDV and had no effect on IBDV infection preinoculation, during mixed inoculation, and post-inoculation. These results may be due to the activity of phytochemical agents in herbal extracts, where post-inoculation treatment consistently outperformed preinoculation and mixed treatments.

These findings coincided with many investigations on aqueous and alcoholic extracts against IBDV. Aslam et al. [39] revealed a 100\% inhibitory effect for methanolic extracts of 11 Cholistani plants and effectiveness in controlling the growth of poultry viruses, such as IBDV and infectious bronchitis, under in vitro conditions. Ahmad et al. [40] illustrated the ethanolic extracts of different plants, including Glycyrrhiza glabra, Moringa oleifera, Phyllanthus emblica, and Eugenia jambolana, against IBDV. Virmani et al. [41] reported that aqueous and alcoholic extracts of $M$. oleifera, Holarrhena antidysenterica, Synzium aromaticum, Allium sativum, Piper nigrum, and Azadirachta indica were effective in controlling IBDV growth. The anti-IBDV activity of root Withania somnifera hydroalcoholic extracts was also reported [42].

The secondary metabolites in the QI, CiA, and CoA extracts in this study, including tannin, phenol, saponin, flavonoid, terpenoid, glycoside, resin, and alkaloid, act as bioactive components with effective therapeutic value [51,52]. Furthermore, several reports indicated the phytochemical ingredients of these extracts. Nutrients and herbal medicines are effective antiviral, antioxidant, anticancer, antibacterial, anti-inflammatory, and cardioprotective agents, promote immune response, and are interesting candidates for healthcare and biopharmaceutical applications [53-56]. These phytochemicals use a variety of mechanisms to prevent viral replication and control viral infection. These mechanisms block viral binding to prevent viral attachment sites or host receptors. Other strategies include inhibiting viral replication by attacking the viral enzyme (DNA or RNA polymerase, reverse transcriptase, and protease) or the 
viral assembly by inhibiting posttranslationally modified viral proteins $[57,58]$.

The inhibitory effect of viral growth in chick embryos is mainly attributed to the phytochemical components (tannin, flavonoid, and phenolic compounds) detected in this study. Cheng et al. [59] revealed that tannin, flavonoid, and phenolic compounds are traditional medicines used to treat various health issues, including herpes simplex virus type 2 . Furthermore, Ashok and Upadhyaya [60] showed that tannin is used as an astringent, providing a plethora of natural sources for treating inflamed and injured tissues, such as burns, and preventing infections. Perin et al. [61] illustrated the phytochemicals used to treat mouth and throat inflammation, gastritis, irritable bowel disorders, and other illnesses. Tannin forms a protective layer on the cellular surface and multiple hydrogen bonds between their phenolic groups and the $\mathrm{NH}$ groups of the peptides that cause protein shrinkage. This was supported by Ghildiyal et al. [62], who showed that phytochemicals, such as flavonoids, are used as antivirals because of the inhibition of protein phosphorylation that limits viral RNA replication.

Furthermore, several researchers exhibited that tannin has significant biological activities with antiviral activity against a wide range of DNA and RNA viruses. These biological activities attack extracellular virions by inhibiting different steps of viral replication, including viral attachment to cell receptors, viral penetration, viral assembly, and transport proteins, polysaccharides, and viral enzymes [63]. Furthermore, the activity of tannins is mainly attributed to their ability to bind to viral structural or nonstructural proteins (capsid or viral enzymes) necessary for viral replication or structural proteins involved in the creation of new viral particles [64].

The flavonoid, a polyphenolic phytochemical component, detected in the extracts in this study has antiviral activity against viruses, particularly segmented RNA viruses [64]. Zakaryan et al. [65] described the antiviral activity of baicalein, a flavonoid that inhibits the various steps of viral RNA replication. Another flavonoid, fisetin, was successfully reported to inhibit virus replication in vitro [66]. In addition, flavonoids have been linked to the inhibition of intracellular viral replication in the early stages $[66,67]$. Furthermore, flavonoid antiviral activity is due to the high water solubility of their structure, which has been recognized as metabolites, and small molecules responsible for detoxification and boosted biological effects. Sodium rutin sulfate inhibited viral replication and blocked virus entry into host cells by interrelating with the glycoprotein of the viral envelope. Previous study has suggested that viral RNA polymerase inhibition is possible [64].

Another secondary metabolite detected in this study is terpene, which acts as a viral inhibitor. Terpenes consist of five carbon isoprene units linked by simple hydrocarbons. Terpenoids are simply modified terpenes and have different functional groups at various positions. Terpenoids, also referred to as isoprenoids, are naturally found in plants and have a significant role in herbal treatments with many medical applications [60]. According to Fayyad et al. [68], terpenes can disrupt virus attachment to the cellular membrane and inhibit viral DNA replication. Similarly, Yang et al. [69] extracted and tested terpenoids for antiviral activity against RNA viruses, and these compounds inhibited viral replication by preventing viral structural protein synthesis and inhibiting genes responsible for coding the viral spike, viral membrane protein, and viral nucleocapsid protein.

However, most components of the secondary metabolites detected in this study include tannins, flavonoids, and phenolic acids that have antioxidant activity and are broadly distributed in several plants, acting as a protective mechanism against oxidative stress. Overproduction of free radicals, and the subsequent emergence of oxidative stress, is a pathogenic factor in various viral infections. Oxidative damage is a multifaceted biochemical state that occurs when oxidative stress on biomolecules increases and the oxidation of nonprotein and protein thiol groups controls the oxidative stability of a cell [69]. Cellular damage caused by viral infection generated through free radical overproduction has been related to $>200$ clinical illnesses [70]. Many viral infections cause the production of reactive oxygen and nitrogen species linked to epithelial wall dysfunction and lung tissue damage, increasing susceptibility to secondary infections [71]. As a result, antioxidant treatment is an appealing and effective treatment approach for viral infections. The antioxidant properties for several tannin-rich extracts are effective against the development of many RNA or DNA viral infections, improving survival rates while considerably decreasing lipid peroxidation and increasing the oxygen radical absorbance capacity in splenocytes $[72,73]$.

The presence of flavonoids and resins, the phytochemical components detected in this study, indicates the antiviral activity of these components. These results agreed with Pang et al. [74], who detected the inhibition of viral replication in the tested resins. The antioxidant activity of resins against viral infections is complemented by intense changes in cell-tissue metabolism, resulting in the severe generation of reactive oxygen species [75]. Alkaloids are also one of the secondary metabolites of these extracts in this study. Some plants from other studies have a nitrogen atom in their ring structure. They are observed at higher plants and have various biological activities, including antiviral, antifungal, antibacterial, anticancer, and antiasthmatic properties. Approximately 43 alkaloids have anti-RNA virus activity. The antiviral activity of alkaloids against RNA viruses may be due to the induction of immune system interferons. Some alkaloids stimulate macrophage activity, allowing them to phagocytose and destroy the virus. At various stages 
of replication, alkaloids inhibit RNA viral infection. Some of them either inhibit viral protein synthesis or interfere with other stages of replication [76,77].

In addition, the phytochemicals detected in this study, such as tannins, glycosides, and saponins, may have immunomodulatory properties. Tannins have immunomodulatory effects, with various substances exhibiting various mechanisms of action that improve macrophage functionality or induce the excretion of cytokines, including interleukin (IL)-1, IL-2, and tumor necrosis factor [63]. Guo et al. [78] found that glycosides have the ability to inhibit viral replication and enhance the innate immune system against RNA viruses. Saponins have been found in a variety of higher plants and have a broad range of pharmacological activities, for example, anti-inflammatory, vasoprotective, gastroprotective, and immunomodulatory effects. Saponins stimulate the components of a specific immunity as well as monocyte proliferation. Saponin, either as a crude mixture or as a purified compound, has increased immune-cell proliferation and antibody production in vitro [79].

\section{Conclusion}

The inoculation of herbal extracts, particularly triextracts, alleviates the pathological changes in ECEs infected with IBDV. This study recommends the oral route in evaluating QI, CiA, and CoA extracts against IBDV in chickens.

\section{Authors' Contributions}

RSJ: Designed the experiment. RSJ and AJK: Interpreted the data and drafted the manuscript. DIA and RSJ: Carried out the experiment, investigation, and resources, DIA, AJK, RSJ. RSJ, and AJK: Performed the statistical analysis and edited the manuscript. All authors have read and agreed to the published version of the manuscript.

\section{Acknowledgments}

The authors express their gratitude to The Head, Department of Microbiology, College of Veterinary Medicine, University of Baghdad, for providing the necessary facilities for this study. This study was funded by the College of Veterinary Medicine, University of Baghdad.

\section{Competing Interests}

The authors declare that they have no competing interests.

\section{Publisher's Note}

Veterinary World remains neutral with regard to jurisdictional claims in published institutional affiliation.

\section{References}

1. Sharma, J. (2000) Infectious bursal disease virus of chickens: Pathogenesis and immunosuppression. Dev. Comp. Immunol., 24(2-3): 223-235.
2. Arafat, N., Eladl, A.H., Marghani, B.H., Saif, M.A. and El-Shafei, R.A. (2018) Enhanced infection of avian Influenza virus $\mathrm{H} 9 \mathrm{~N} 2$ with infectious laryngotracheitis vaccination in chickens. Vet. Microbiol., 219(6): 8-16.

3. Jakka, P., Reddy, Y.K., Kirubaharan, J.J. and Chandran, N.D.J. (2014) Evaluation of immune responses by live infectious bursal disease vaccines to avoid vaccination failures. Eur. J. Microbiol. Immunol., 4(2): 123-127.

4. Alkie, T.N. and Rautenschlein, S. (2016) Infectious bursal disease virus in poultry: Current status and future prospects. Vet. Med., 7(1): 9-18.

5. Eladl, A.H., Mosad, S.M., El-Shafei, R.A., Saleh, R.M., Ali, H.S., Badawy, B.M. and Elshal, M.F. (2020) Immunostimulant effect of a mixed herbal extract on infectious bursal disease virus (IBDV) vaccinated chickens in the context of a co-infection model of avian influenza virus H9N2 and IBDV. Comp. Immunol. Microbiol. Infect. Dis., 72(10): 101505 .

6. Nagah, A., Eladl, A.H.M. and Reham, A.E. (2017) Effect of infectious bursal disease (IBD) vaccine on Salmonella enteritidis infected chickens. Vaccine, 35(29): 3682-3689.

7. Samah, M.M., Abdelfattah, H.E., Mohamed, E.T., Hanaa, S.A. and Mohamed F.H. (2020) Molecular characterization and pathogenicity of very virulent infectious bursal disease virus isolated from naturally infected turkey poults in Egypt. Trop. Anim. Health Prod., 52(6): 3819-3831.

8. Latif, I.K., Karim, A.J., Zuki, A.B.Z., Zamri-Saad, M., Niu, J.P. and Noordin, M.M. (2011) Efficacy of Nigella sativa in alleviating benzo [a] pyrene-induced immunotoxicity in broilers. Histo. Histopathol., 26(6): 699-710.

9. Al-Gburi, R.S.J., Al-Banna, A.S., Ibrahim, O.M.S. and Odisho, S.M. (2013) Role of poultry star and alcoholic Myristica fragrans extract on calf rotavirus diarrhea. Al-Anbar. J. Vet. Sci., 6(1): 65-69.

10. Al-Amri, S.A., Shony, M.O. and Orooba, M.S.I. (2015) In vitro antiviral potential of Ocimum basilicum and Olea europaea leaves extract against Newcastle disease virus of poultry. Iraqi J. Vet. Med., 39(1): 94-99.

11. Jumaa, R.S. (2017) Antiviral effect of Myristica fragrans on calf Rotavirus (in vitro). Int. J. Sci. Nat., 8(1): 122-127.

12. Altaee, E.H., Karim, A.J. and Dakheel, M.M. (2020) Assessment of anti-diabetic activity of Vinca Rosea extract on induced diabetic mice. Indian. J. Foren. Med. Toxicol., 14(4): 2311-2318

13. Tayel, A.A., El-Sedfy, M.A., Ibrahim, A.I. and Moussa, S.H. (2018) Application of Quercus infectoria extract as a natural antimicrobial agent for chicken egg decontamination. Rev. Argent. Microbiol., 24(3): 24-30.

14. El-Shafei, R.A., Eladl, A.H., Hamed, H.R. and Abou El-Amaiem, W.E. (2014) Competency of commercially available medicaments on treatment of chicken cryptosporidiosis. Int. J. Innov. Appl. Stud., 6(4): 758-767.

15. Latif, I.K., Karim, A.J., Zuki, A.B., Zamri-Saad, M. and Noordin, M.M. (2011) Nigella sativa meal alleviates injury against benzo [a] pyrene exposures in broilers. Pertanika J. Trop. Agric. Sci., 34(1): 157-162.

16. Gharagozloo, M. and Ghaderi,A. (2001)Immunomodulatory effect of concentrated lime juice extract on activated human mononuclear cells. J. Ethnopharmacol., 77(1): 85-90.

17. Poulose, S.M., Harris, E.D. and Patil, B.S. (2005) Citrus limonoids induce apoptosis in human neuroblastoma cells and have radical scavenging activity. J. Nutr., 135(4): 870-877.

18. Jayaprakasha, G.K., Mandadi, K.K., Poulose, S.M., Jadegoud, Y., Gowda, G.N. and Patil, B.S. (2008) Novel triterpenoid from Citrus aurantium L. Possesses chemopreventive properties against human colon cancer cells. Bioorg. Med. Chem., 16(11): 5939-5951.

19. Chaiyana, W. and Okonogi, S. (2012) Inhibition of cholinesterase by essential oil from food plant. J. Phytomed., 19(8-9): 836-839.

20. Pourhossein, Z., Qotbi, A.A.A., Seidavi, A., Laudadio, V., 
Centoducati, G. and Tufarelli, V. (2015) Effect of different levels of dietary sweet orange (Citrus sinensis) peel extract on humoral immune system responses in broiler chickens. Anim. Sci. J., 86(1): 105-110.

21. Enejoh, O.S., Ogunyemi, I.O., Bala, M.S., Oruene, I.S., Suleiman, M.M. and Ambali, S.F. (2015) Ethnomedical importance of Citrus aurantifolia (christm) swingle. Pharma. Innov., 4(8): 1.

22. Karmee, S.K. (2018) A spent coffee grounds based biorefinery for the production of biofuels, biopolymers, antioxidants and biocomposites. J. Waste. Manage., 72(2): 240-254.

23. Iriondo-DeHond, A., Garcia, N.A., Fernandez-Gomez, B., Guisantes-Batan, E., Escobar, F.V., Blanch, G.P. and del Castillo, M.D. (2019) Validation of coffee by-products as novel food ingredients. Innov. Food. Sci. Emerg. Technol., 51(1): 194-204.

24. Malara, A., Paone, E., Frontera, P., Bonaccorsi, L., Panzera, G. and Mauriello, F. (2018) Sustainable exploitation of coffee silverskin in water remediation. Sustain. J., 10(10): 3547.

25. Nzekoue, F.K., Angeloni, S., Navarini, L., Angeloni, C., Freschi, M., Hrelia, S. and Caprioli, G. (2020) Coffee silverskin extracts: Quantification of 30 bioactive compounds by a new HPLC-MS/MS method and evaluation of their antioxidant and antibacterial activities. Food Technol. Int., 133(7): 109-128.

26. Kamgang Nzekoue, F., Khamitova, G., Angeloni, S., Sempere, A.N., Tao, J., Maggi, F. and Caprioli, G. (2020) Spent coffee grounds: A potential commercial source of phytosterols. Food Chem., 325(9): 126-836.

27. Bessada, S.M., Alves, R. and Oliveira, M.B. (2018) Coffee silverskin: A review on potential cosmetic applications. Cosmetics, 5(1): 5.

28. Ali, H.S., Mansour, A.F., Kamil, M.M. and Hussein, A.M.S. (2018) Formulation of nutraceutical biscuits based on dried spent coffee grounds. Int. J. Pharmacol., 14(4): 584-594.

29. Bertolino, M., Barbosa-Pereira, L., Ghirardello, D., Botta, C., Rolle, L., Guglielmetti, A. and Zeppa, G. (2019) Coffee silverskin as nutraceutical ingredient in yogurt: Its effect on functional properties and its bioaccessibility. $J$. Sci. Food Agric., 99(9): 4267-4275.

30. Mussatto, S.I., Ballesteros, L.F., Martins, S. and Teixeira, J.A. (2011) Extraction of antioxidant phenolic compounds from spent coffee grounds. Sep. Purif. Technol., 83(1): 173-179.

31. Mariotti-Celis, M.S., Martínez-Cifuentes, M., HuamánCastilla, N., Vargas-González, M., Pedreschi, F. and PérezCorrea, J.R. (2018) The antioxidant and safety properties of spent coffee ground extracts impacted by the combined hot pressurized liquid extraction-resin purification process. Molecules, 23(1): 21.

32. Granato, D., Shahidi, F., Wrolstad, R., Kilmartin, P., Melton, L.D., Hidalgo, F.J. and Finglas, P. (2018) Antioxidant activity, total phenolics and flavonoids contents: Should we ban in vitro screening methods? Food Chem., 264(10): 471-475.

33. Zheng, Y., Yang, W., Sun, W., Chen, S., Liu, D., Kong, X. and Ye, X. (2020) Inhibition of porcine pancreatic $\alpha$-amylase activity by chlorogenic acid. J. Funct. Foods, 64(1): 103-587.

34. Oboh, G., Agunloye, O.M., Adefegha, S.A., Akinyemi, A.J. and Ademiluyi, A.O. (2015) Caffeic and chlorogenic acids inhibit key enzymes linked to Type 2 diabetes (in vitro): A comparative study. J. Basic. Clin. Physiol. Pharmacol., 26(2): 165-170.

35. Szwajgier, D. (2015) Anticholinesterase activity of selected phenolic acids and flavonoids-interaction testing in model solutions. Ann. Agric. Environ. Med., 22(4): 690-694.

36. Pohanka, M. and Dobes, P. (2013) Caffeine inhibits acetylcholinesterase, but not butyrylcholinesterase. Int. J. Mol. Sci., 14(5): 9873-9882.

37. Orhan, I.E. (2019) Enzyme inhibitors as the attractive targets for the treatment of various diseases. Curr. Med. Chem.,
26(18): 3206-3207.

38. Zengin, G., Sinan, K.I., Mahomoodally, M.F., Angeloni, S., Mustafa, A.M., Vittori, S. and Caprioli, G. (2020) Chemical composition, antioxidant and enzyme inhibitory properties of different extracts obtained from spent coffee ground and coffee silverskin. Foods, 9(6): 713.

39. Aslam, A., Shahzad, M.I., Parveen, S., Ashraf, H., Naz, N., Zehra, S.S. and Mukhtar, M. (2016) Evaluation of antiviral potential of different Cholistani plants against infectious bursal disease and infectious bronchitis virus. Pak. Vet. J., 36(3): 302-306.

40. Ahmad, W., Ejaz, S., Anwar, K. and Ashraf, M. (2014) Exploration of the in vitro cytotoxic and antiviral activities of different medicinal plants against infectious bursal disease (IBD) virus. Open Life Sci., 9(5): 531-542.

41. Virmani, M., Kapoor, S., Garg, S.L. and Virmani, N. (2009) In vitro antiviral activity of plant extracts against infectious bursal disease virus. J. Immunol. Immunopathol., 11(1): 48-52.

42. Abdelfattah, H.E., Nagah, A., Reham, A.S., Verginia, M.F., Rasha, M.S. and Walaa F.A. (2019) Comparative immune response and pathogenicity of the H9N2 avian influenza virus after administration of immulant, based on Echinacea and Nigella sativa, in stressed chickens. Comp. Immunol. Microbiol. Infect. Dis., 65(8): 165-175.

43. Mutinda, W.U., Njagi, L.W., Nyaga, P.N., Bebora, L.C., Mbuthia, P.G., Kemboi, D. and Muriuki, A. (2015) Isolation of infectious bursal disease virus using indigenous chicken embryos in Kenya. Int. Sch. Res. Notices, 2015: 464376.

44. Reed, L.J. and Muench, H. (1938) A simple method of estimating fifty percent endpoint. Am. J. Epidemiol., 27(3): 493-497.

45. El-Rabey, H.A., Rezk, S.M., Sakran, M.I., Mohammed, G.M., Bahattab, O., Balgoon, M.J. and Bakry, N. (2021) Green coffee methanolic extract and silymarin protect against $\mathrm{CCl} 4$-induced hepatotoxicity in albino male rats. BMC Complement. Med. Ther., 21(1): 1-11.

46. Harborne, J.B. (1984) Phytochemical Methods a Guide to Modern Techniques of Plant Analysis. $2^{\text {nd }}$ ed., Vol. 39. Chapman and Hall, London and New York. p236.

47. Banso, A. and Adeyemo, A. (2006) Phytochemical screening and antimicrobial assessment of Abutilon mauritianum, Bacopa monnifera and Datura stramonium. Biokemistri, 18(1): 39-44.

48. Jumaa, R.S., Aida, B.A. and Rebah, N.J. (2019) Isolation of infectious bursal disease virus and immuno histochemistry of $\mathrm{Cd} 4+$ and $\mathrm{Cd} 8+$ for infected Iraqi chickens. Biochem. Cell. Arch., 19(2): 3375-3384.

49. Cheggag, M., Zro, K., Sebbar, G., Rahmatallah, N., Mouahid, M. and El Houadf, M. (2018) Diagnosis of clinical cases of infectious bursal disease using a modified rapid taq man-MGB real-time RT-PCR assay. J. Agric. Sci. Technol. A., 8: 230-238.

50. Jumaa, R.S., Aida, B.A. and Rebah, N.J. (2020) Genetic analysis of field isolates of infectious bursal disease virus in Iraqi farms. Iraqi J. Vet. Med., 44(1): 18-28.

51. Elham, A., Arken, M., Kalimanjan, G., Arkin, A. and Iminjan, M. (2020) A review of the phytochemical, pharmacological, pharmacokinetic, and toxicological evaluation of Quercus infectoria Galls. J. Ethnopharmacol., 273(6): 113592.

52. Chen, X. (2019) A review on coffee leaves: Phytochemicals, bioactivities, and applications. Crit. Rev. Food Sci. Nutr., 59(6): 1008-1025.

53. Karak, P. (2019) Biological activities of flavonoids: An overview. Int. J. Pharm. Sci. Res., 10(4): 1567-1574.

54. Andreu, L., Nuncio-Jáuregui, N., CarbonellBarrachina, Á.A., Legua, P. and Hernández, F. (2018) Antioxidant properties and chemical characterization of Spanish Opuntia ficus-indica Mill. Cladodes and fruits. $J$. Sci. Food. Agric., 98(4): 1566-1573.

55. Meng, X.H., Liu, C., Fan, R., Zhu, L.F., Yang, S.X., 
Zhu, H.T. and Zhang, Y.J. (2018) Antioxidative flavan-3-ol dimers from the leaves of Camellia fangchengensis. $J$. Agric. Food. Chem., 66(1): 247-254.

56. Tungmunnithum, D., Thongboonyou, A., Pholboon, A. and Yangsabai, A. (2018) Flavonoids and other phenolic compounds from medicinal plants for pharmaceutical and medical aspects: An overview. Medicines, 5(3): 93.

57. Subudhi, B.B., Chattopadhyay, S., Mishra, P. and Kumar, A. (2018) Current strategies for inhibition of chikungunya infection. J. Viruses, 10(5): 235.

58. Lipson, S.M., Karalis, G., Karthikeyan, L., Ozen, F.S., Gordon, R.E., Ponnala, S. and Wolfe, E. (2017) Mechanism of anti-rotavirus synergistic activity by epigallocatechin gallate and a proanthocyanidin-containing nutraceutical. Food Environ. Virol., 9(4): 434-443.

59. Cheng, H.Y., Lin, C.C. and Lin, T.C. (2002) Antiherpes simplex virus Type 2 activity of casuarinin from the bark of Terminalia arjuna Linn. Antiviral Res., 55(3): 447-455.

60. Ashok, P.K. and Upadhyaya, K. (2012) Tannins are astringent. J. Pharmacogn. Phytochem., 1(3): 45-50.

61. Perin, G., Baldissera, M.D., Fernandes, M., Barreta, M., Casagrande, R.A., Griss, L.G. and da Silva, A.S. (2019) Effects of tannin-containing diets on performance, gut disease control and health in broiler chicks. Anim. Prod. Sci., 59(10): 1847-1857.

62. Ghildiyal, R., Prakash, V., Chaudhary, V.K., Gupta, V. and Gabrani, R. (2020) Phytochemicals as antiviral agents: recent updates. In Plant-Derived Bioactives: Production, Properties and Therapeutic Applications. Springer, Berlin, Germany. p279-295.

63. Vilhelmova-Ilieva, N., Galabov, A.S. and Mileva, M. (2019) Tannins as antiviral agents. In: Tannins-structural Properties. Biological Properties and Current Knowledge. IntechOpen, India.

64. Ninfali, P., Antonelli, A., Magnani, M. and Scarpa, E.S. (2020) Antiviral properties of flavonoids and delivery strategies. Nutrients, 12(9): 2534.

65. Zakaryan, H., Arabyan, E., Oo, A. and Zandi, K. (2017) Flavonoids: Promising natural compounds against viral infections. Arch. Virol., 162(9): 2539-2551.

66. Wang, T.Y., Li, Q. and Bi, K.S. (2018) Bioactive flavonoids in medicinal plants: Structure, activity and biological fate. Asian. J. Pharm. Sci., 13(1): 12-23.

67. Wang, C.Y., Chen, Y.W. and Hou, C.Y. (2019) Antioxidant and antibacterial activity of seven predominant terpenoids. Int. J. Food Prop., 22(1): 230-238.

68. Fayyad, A.G., Ibrahim, N. and Yaakob, W.A. (2014) Phytochemical screening and antiviral activity of Marrubium vulgare. Malays. J. Microbiol., 10(2): 106-111.
69. Yang, J.L., Ha, T.K., Dhodary, B., Pyo, E., Nguyen, N.H., Cho, H., Kim, E. and Oh, W.K. (2015) Oleanane triterpenes from the flowers of Camellia japonica inhibit porcine epidemic diarrhea virus (PEDV) replication. J. Med. Chem., 58(3): 1268-1280.

70. Halliwell, B. and Gutteridge, J.M.C. (2007) Cellular responses to oxidative stress: Adaptation, damage, repair, senescence and death. In: Halliwell B, Gutteridge JMC, editors. Free Radicals in Biology and Medicine. $4^{\text {th }}$ ed. Oxford University Press, New York. p187-267.

71. Gacche, R., Khsirsagar, M., Kamble, S., Bandgar, B., Dhole, N. and Shisode, K. (2008) Antioxidant and anti-inflammatory related activities of selected synthetic chalcones: Structure-activity relationship studies using computational tools. Chem. Pharm. Bull., 56(7): 897-901.

72. De Marco, F. (2013) Oxidative stress and HPV carcinogenesis. Viruses, 5(2): 708-731.

73. Cianciosi, D., Forbes-Hernández, T.Y., Afrin, S., Gasparrini, M., Reboredo-Rodriguez, P., Manna, P.P. and Battino, M. (2018) Phenolic compounds in honey and their associated health benefits: A review. Molecules, 23(9): 2322.

74. Pang, J., Dong, W., Li, Y., Xia, X., Liu, Z., Hao, H. and Liu, Y. (2017) Purification of houttuynia cordata thumb, essential oil using macroporous resin followed by microemulsion encapsulation to improve its safety and antiviral activity. Molecules, 22(2): 293.

75. Lu, N., Shen, M., Hou, Z. and Xin, Z. (2018) Effectiveness of different kinds of antioxidants in resin-cured bromobutyl rubber vulcanizates. Adva. Poly. Technol., 37(6): 2075-2084.

76. Hussein, R.A. and El-Anssary, A.A. (2019) Plant secondary metabolites: The key drivers of the pharmacological actions of medicinal plants. J. Herb. Med., 1(1): 13.

77. Meles, D.K., Mustofa, I., Zakaria, S. and Adnyana, I.D.P. (2017) Alkaloid immunomodulatory effects of sambiloto (Andrographis paniculate 1.) on the response of gamma interferon and thelper cell (cd4+). Adva. Nat. Appl. Sci., 11(9): 154-159.

78. Guo, S., Bao, L., Li, C., Sun, J., Zhao, R. and Cui, X. (2020) Antiviral activity of iridoid glycosides extracted from fructus Gardeniae against influenza a virus by PACT-dependent suppression of viral RNA replication. Sci. Rep., 10(1): 1-12.

79. Alhazm, H.A., Najmi, A., Javed, S.A., Sultana, S., Al Bratty, M., Makeen, H.A., Meraya, A.M., Ahsan, W., Mohan, S., Taha, M.M.E. and Khalid, A. (2021) Medicinal plants and isolated molecules demonstrating immunomodulation activity as potential alternative therapies for viral diseases including COVID-19. Front. Immunol., 12(5): 637553.

\section{$* * * * * * * *$}

